\title{
Duchenne muscular dystrophy: negative electroretinograms and normal dark adaptation. Reappraisal of assignment of X linked incomplete congenital stationary night blindness
}

\author{
Hanne Jensen, Mette Warburg, Ole Sjö, Marianne Schwartz
}

\begin{abstract}
Åland Island eye disease (ÅIED) and X linked congenital stationary night blindness (CSNB) have been mapped to Xp11.3. Patients have been described with deletions of the Duchenne muscular dystrophy (DMD) gene who also had a negative electroretinogram (ERG) similar to that seen in patients with CSNB and ÅIED. This seems to confirm that some cases of ÅIED and CSNB map to Xp21.

We examined 16 boys with DMD/BMD (Becker muscular dystrophy) of whom 10 had negative ERGs, eight of them having deletions downstream from exon 44 . Normal dark adaptation thresholds were observed in all patients and there were no anomalous visual functions. Hence, CSNB cannot be assigned to $X p 21$ and negative ERG in DMD/BMD is not associated with eye disease. Six boys with DMD/BMD had normal ERGs. We speculate that a retinal or glial dystrophin may be truncated or absent in the boys with negative ERGs.
\end{abstract}

(f Med Genet 1995;32:348-351)

There are two types of $\mathrm{X}$ linked congenital stationary night blindness (CSNB), complete and incomplete. Linkage studies in families with incomplete CSNB, ${ }^{1}$ complete $\mathrm{CSNB},{ }^{2-6}$ and Åland Island eye disease (ÅIED) ${ }^{78}$ have shown that they all map to Xp11.3. X linked incomplete CSNB and AIED presumably constitute the same genetic disorder. ${ }^{17-11}$

In CSNB and AIIED, the electroretinographic response to a bright light of the dark adapted eye shows a normal a wave and a low or absent $b$ wave, so that the ratio of the amplitudes of the $b$ to the a wave is below $1 \cdot 0$. This is called a negative electroretinogram (ERG). A negative ERG can also be found in a number of other ocular disorders (table).

In a series of papers, Weleber et $a l^{10}$ and Pillers $e t a l^{15-17}$ described patients with complex deletions comprising glycerol kinase deficiency and DMD. The patients had a negative ERG. The observation led them to hypothesise that incomplete CSNB and ÅIED could also be induced by a deletion in the DMD gene at $\mathrm{Xp} 21$.

Five patients with DMD deletions described by Cibis et $a l^{18}$ and six patients with DMD gene deletions observed by De Becker et al ${ }^{19}$ had negative ERGs, similar to ÅIED and incomplete CSNB. This seemed to confirm that some cases of ÅIED and CSNB mapped to $\mathrm{Xp} 21$. Sigesmund $e t a l^{20}$ described 26 patients with DMD/BMD. Five patients, of whom three were brothers, had electroretinographic b/a amplitude ratios $<1 \cdot 0$. Their deletions were exons 14-41, 48-49, and 45. Ten patients had no deletions and four of them had a b/a ratio $<1 \cdot 0$. The rest had normal b/a amplitude ratios. No dark adaptation thresholds were routinely examined in the studies mentioned.

We have observed eight boys with DMD/ BMD resulting from deletions downstream from exon 44. The ERGs had a b/a amplitude ratio $<1 \cdot 0$, dark adaptation thresholds were normal, and there were no visual functional defects. We conclude that a negative ERG associated with deletion of the dystrophin gene is insufficient evidence for mapping CSNB and ÅIED to Xp21.

\section{Methods}

PATIENTS AND CLINICAL EXAMINATIONS

The Danish Patient Association of People with Muscular Disorders agreed to write to their members with $\mathrm{DMD} / \mathrm{BMD}$ suggesting that they reported to us for a full ophthalmological examination, including ERG tracings. Letters were mailed to 48 members with DMD/BMD, 16 of whom, aged 9 to 26 years, accepted the invitation. Two patients were brothers.

The ophthalmological examination consisted of determination of visual acuity for near and distance vision, accommodation, refractive errors, motility, alignment, transillumination of the irides, colour vision, contrast thresholds, Goldmann visual fields, and dark adaptation measured in the right eye by the GoldmannWeekers apparatus. The patients were tested for glycerol excretion in the urine.

Retinal disorders with negative ERG adapted from references $10,12,13$, and 14 .

$\mathrm{X}$ linked congenital stationary night blindness (CSNB) Åland Island eye disease (ÅIED)

Autosomal recessive CSNB

Juvenile $\mathrm{X}$ linked retinoschisis

The enhanced $S$ cone syndrome

Goldmann-Favre syndrome

Retinitis pigmentosa, special type

Carriers of some types of retinitis pigmentosa

Cone dystrophy

Optic neuropathy

Other retinal vascular disorders 


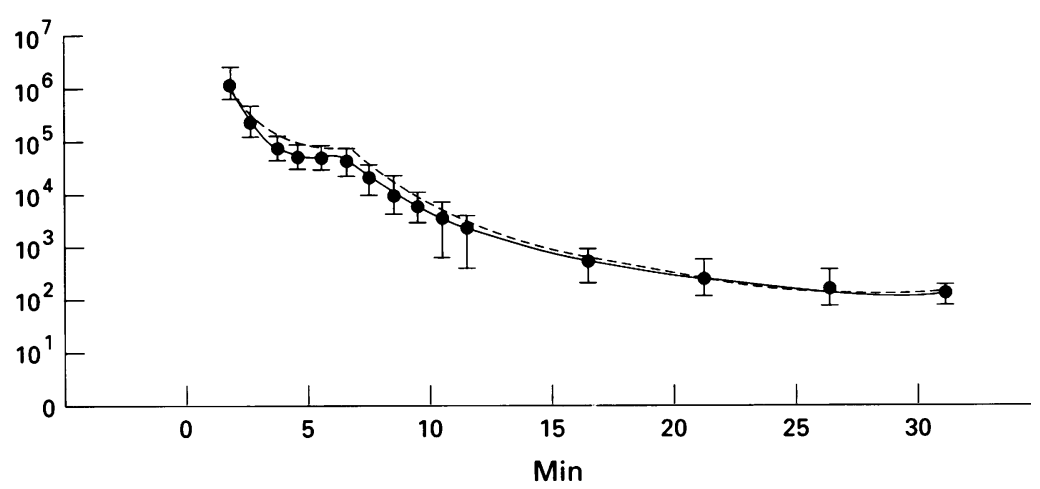

Figure 1 Dark adaptation in patients with DMD/BMD. The patients were examined with the Goldmann-Weekers' apparatus. The dashed line shows mean results from normal subjects. The panel shows dark adaptation in boys with deletions in the middle part of the Duchenne gene. The bars present the range of clinical measurements. The abscissa shows time of adaptation in minutes, the ordinate shows the reduction of light in arbitrary units given on the instrument.

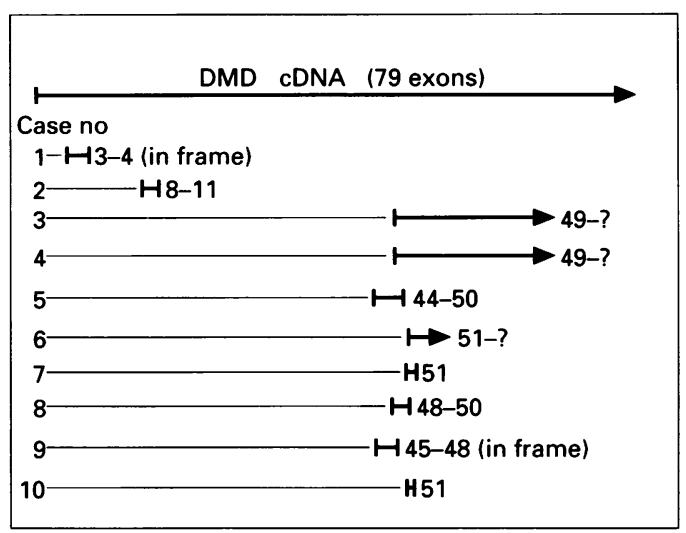

Figure 2 Deleted exons in 16 boys with Duchenne and Becker muscular dystrophy.
ELECTRORETINOGRAPHY

ERGs were performed on the right eye on all patients and their mothers following the international guidelines. ${ }^{21}$ The stimuli were elicited with a Nicolet Ganzfield dome and the patients were dark adapted for 30 minutes. The response of the dark adapted eye to a bright white flash was assessed with maximal light intensity.

\section{DELETION ANALYSES}

DNA was isolated by routine methods. Deletion analysis was performed by PCR including the 9-plex PCR kit, designed by Chamberlain et $a l^{22}$ and Beggs et $a l^{23}$ respectively. Furthermore, HindIII digested DNA was subjected to Southern blot analysis using cDNA probes ${ }^{24}$ in order to determine the extension of the deletions.

\section{Results}

The 16 boys complied bravely with all examinations. The patients had normal visual acuities, contrast threshold, colour vision, visual fields, and dark adaptation (fig 1). The irides were not transparent and glycerol excretion was not increased in any patient.

The deletions observed are shown in fig 2 . Eight boys had deletions in the middle part of the gene, and two in the $5^{\prime}$ end of the dystrophin gene; in six patients no deletion was detected.

Ten boys had negative ERGs (fig 3), eight of whom had deletions of exons downstream from exon 44, while two had no discernible deletion. ERGs showed b/a amplitude ratios $>1.0$ in two boys with deletions of exons 3-4 and $8-11$, respectively, and in four patients without deletions, two of whom were brothers. ERGs were normal in all mothers.

\section{Discussion}

\section{DIFFERENTIAL DIAGNOSIS}

ERG is negative in CSNB; in complete CSNB there is no trace of rod dark adaptation, while in incomplete CSNB dark adaptation is present, but the thresholds are raised. Even in the oldest of our patients with negative ERGs we found no sign of defective dark adaptation; hence complete and incomplete X linked congenital stationary night blindness could be excluded.

Dark adaptation in patients with the AIED showed defective rod dark adaptation, similar to curves from patients with incomplete CSNB. ${ }^{1125}$ Typical findings in ÅIED are negative ERGs, impaired visual acuity, nystagmus, myopia, astigmatism, and colour vision defect. ${ }^{26}$ Apart from the negative ERGs, none of these signs was observed in our patients.

A negative ERG is found in a number of retinal disorders (table), but none of them was present in our patients with DMD/BMD. Our patients had normal fundi, no abnormalities of their visual psychophysic responses, and normal visual fields. There were no signs of cone dystrophy.
Figure 3 The top curve is an electroretinogram from a patient with a deletion of the Duchenne gene and a b/a wave amplitude ratio of $<1 \cdot 0$. The bottom curve shows a normal electroretinogram for comparison. The $a$ and $b$ waves are indicated. 
DYSTROPHIN DELETIONS AND ERG RESPONSE We found ERGs with a b/a amplitude ratio $<1 \cdot 0$ in all patients with deletions of exons downstream from exon 44 (fig 2). ERGs with a b/a amplitude ratio $>1.0$ were present in boys with deletions of exons 3-4 and 8-11, and in four boys with no detectable deletion. Others ${ }^{17-20}$ have also found negative ERGs in patients with $\mathrm{DMD} / \mathrm{BMD}$ who had deletions including exons 41-48, but De Becker et al ${ }^{19}$ also had a patient with a deletion of exon 3 who had a negative ERG.

Our patients were a random series of young boys who presented themselves in response to a letter from their patient organisation. Deletions were found in $63 \%$, a percentage in accordance with other unselected series of DMD patients. ${ }^{27}$

Dystrophin can be shown in the retina by immunohistochemical methods. Transcription of the dystrophin gene involves at least five distinct promoters, each of them driving cell specific dystrophins. ${ }^{28}$ Different dystrophins are present in the brain, muscle, Purkinje cells, Schwann cells, and glial cells, ${ }^{28}$ and are transcribed by alternative splicing.

Dystrophin is normally present in the photoreceptor-bipolar synaptic complex ${ }^{29-31}$ of the retina in humans and mice. Signals derived from these synapses and the Müller cells drive the $b$ wave of the ERG and Fitzgerald et $a l^{32}$ found evidence of dysfunction of the photoreceptor-bipolar pathway in patients with DMD.

Brain dystrophin, muscle dystrophin, and some of the C-terminal splice variants are present in the outer nuclear layer of the retina. A specific retinal dystrophin with its own promoter has not been reported, and the function of the dystrophins in the retina is unknown.

THE POSITIONAL RELATION OF THE GENES FOR DMD/BMD AND $X$ LINKED CSNB

Complete and incomplete CSNB and ÅIED are mapped to $\mathrm{Xp} 11.3^{1-8}$ and incomplete CSNB and AIED presumably constitute the same nosological entity ${ }^{7-11}$ or allelic disorders. ${ }^{1}$

Patients with DMD/BMD but without complex deletions also had negative ERGs similar to those observed in incomplete CSNB. ${ }^{17-20} \mathrm{It}$ was therefore surmised that incomplete CSNB and AIED might also be assigned to Xp21. ${ }^{10}$

Our results show that although patients with deletions downstream from exon 44 do in fact have negative ERGs they have no deficiency of their dark adaptation thresholds or other clinical visual functions. Thus the patients have an asymptomatic ERG anomaly, and the assignment of CSNB or ÅIED to Xp21 cannot be upheld.

\section{Conclusion}

In 16 unselected patients with $\mathrm{DMD} / \mathrm{BMD}$, 10 had negative ERGs, similar to the responses in $\AA$ IED and CSNB, but they had normal clinical ophthalmological functions and no measurable night blindness and therefore no CSNB. This shows that CSNB cannot be as- signed to $\mathrm{Xp} 21$ and that negative ERG in $\mathrm{DMD} / \mathrm{BMD}$ is not associated with eye disease.

We are indebted to the patients who cooperated with us in an admirable way in spite of their serious impairments. We also thank the families of the patients who helped us in many thank the families of the patients who helped us in many
ways. This study was supported by grants from the VELUX ways. This study was supported by grants from the VELUX Foundation, the National Danish Foundation, Save the Sight
(Landsforeningen, Vaern om Synet), and the Danish Association (Landsforeningen, Vaern om Synet), and the Danish Association
of the Blind. We thank Drs S E Simonsen and S Nørby for of the Blind. We than
instructive discussions.

1 Glass IA, Good P, Coleman MP, et al. Genetic mapping of a cone and rod dysfunction (Aland Island eye disease) to the proximal short arm of the human $\mathrm{X}$ chromosome. $\mathcal{F}$ Med Genet 1993;30:1044-50.

2 Gal A, Schinzel A, Orth U, et al. Gene of X-chromosomal congenital stationary night blindness is closely linked to DXS7 on Xp. Hum Genet 1989;81:315-18.

3 Musarella MA, Weleber RG, Murphey WH, et al. AsMusarella MA, Weleber RG, Murphey WH, et al. As-
signment of the gene for complete X-linked congenital signment of the gene for complete X-linked congenital
stationary night blindness (CSNB1) to Xp11.3. Genomics 1989;5:727-37

4 Bech-Hansen NT, Field LL, Schramm AM, et al. A locus for $\mathrm{X}$-linked congenital stationary night blindness is located on $\mathrm{X}$-linked congenital stationary night blindness is located on
the proximal portion of the short arm of the $\mathrm{X}$ chrothe proximal portion of the short arm
mosome. Hum Genet 1990;84:406-8.

5 Bech-Hansen NT, Moore BJ, Pearce WG. Mapping of locus for X-linked congenital stationary night blindness (CSNB1) proximal to DXS7. Genomics 1992;12:409-11.

6 Orth U, Schinzel A, Mächler M, Gal A. X-chromosomal erbliche Nachtblindheit: Erkennen von Überträgerinnen durch Segregationsanalyse mit gekoppelten DNAMarkern. Klin Monatsbl Augenheilkd 1990;196:269-72.

7 Alitalo T, Kruse TA, Forsius H, Eriksson AW, de la Chapelle A. Localization of the Alland Island eye disease locus to the pericentromeric region of the $\mathrm{X}$ chromosome by linkage analysis. Am F Hum Genet 1991;48:31-8.

8 Schwartz M, Rosenberg T. Åland Island eye disease: linkage data. Genomics 1991;10:327-32.

9 Krill AE. Congenital stationary night blindness. In: Krill $\mathrm{AE}$, Archer DB, eds. Krill's hereditary retinal and choroidal diseases. New York: Harper \& Row, 1977:391-420.

10 Weleber RG, Pillers DM, Powell BR, Hanna CE, Magenis RE, Buist NRM. Aland Island eye disease (Forsius-EriksRE, Buist NRM. Aland Island eye disease (Forsius-Eriksson syndrome) associated with contiguous deletion syndrome at Xp21. Similarity to incomplete congent
blindness. Arch Ophthalmol 1989;107:1170-9.

11 Rosenberg T, Schwartz M, Simonsen SE. Åland Island eye disease (Forsius-Eriksson-Miyake syndrome) with probability established in a Danish family. Acta Ophthalmol ability established in a

12 Cideciyan AV, Jacobson SG. Negative electroretinograms in retinitis pigmentosa. Invest Ophthalmol Vis Sci 1993;34: retinitis pign

13 Weleber RG, Miyake Y. Familial optic atrophy with negative electroretinograms. Arch Ophthalmol 1992;110:640-5.

14 Kellner U, Foerster MH. Cone dystrophies with negative photopic electroretinogram. $\mathrm{Br} \mathcal{F}$ Ophthalmol 1993;77: 404-9.

15 Pillers DM, Weleber RG, Powell BR, Hanna CE, Magenis RE, Buist NRM. Åland Island eye disease (Forsius-Eriksson ocular albinism) and an $\mathrm{Xp} 21$ deletion in a patient with Duchenne muscular dystrophy, glycerol kinase deficiency, and congenital adrenal hypoplasia. Am $\mathcal{F}$ Med Genet 1990; 36:23-8.

16 Pillers DA, Towbin JA, Chamberlain JA, et al. Deletion mapping of Âland Island eye disease to Xp21 between DXS67 (B24) and Duchenne muscular dystrophy. $A m \mathcal{F}$ Hum Genet 1990;47:795-801.

17 Pillers DM, Seltzer WK, Powell BR, et al. Negative configuration electroretinogram in Oregon eye disease. Consistent phenotype in Xp21 deletion syndrome. Arch Ophthalmol 1993;111:1558-63.

18 Cibis GW, Fitzgerald KM, Harris DJ, Rothberg PG, Rupani $M$. The effects of dystrophin gene mutations on the ERG in mice and humans. Invest Ophthalmol Vis Sci 1993;34: in mice and

19 De Becker I, Riddell DC, Dooley JM, Tremblay FC. Correlation between electroretinogram findings and molecular relation between electroretinogram findings and molecular analysis in the Duchenne muscular
$B r \mathcal{F}$ Ophthalmol 1994;78:719-22.

20 Sigesmund DA, Weleber RG, Pillers DAM, et al. Characterization of the ocular phenotype of Duchenne and Becker muscular dystrophy. Ophthalmology 1994;101:85665.

21 Marmor MF, Arden GB, Nilsson SEG, Zrenner E. Standard for clinical electroretinography. Arch Ophthalmol 1989; 107:816-19.

22 Chamberlain JS, Gibbs RA, Rainer JE, Nguyen PN, Caskey TC. Deletion screening of the Duchenne muscular dysTC. Deletion screening of the Duchenne muscular dys-
trophy locus via multiplex DNA amplification. Nucleic trophy locus via multiplex

23 Beggs AH, Koenig M, Boyce FM, Kunkel LM. Detection Beggs AH, Koenig M, Boyce FM, Kunkel LM. Detection of $98 \%$ of DMD/BMD gene deletions

24 Koenig M, Hoffman EP, Bertelson CJ, Monaco AP, Feener Coenig M, Hoffman EP, Bertelson CJ, Monaco AP, Feener cular dystrophy (DMD/BMD) cDNA and preliminary 
genomic organization of the DMD/BMD gene in normal and affected individuals.

25 Carlson S, Vesti E, Raitta C, Donner M, Eriksson AW, Forsius $\mathrm{H}_{\mathrm{B}}$. Clinical and electroretinographic comparison between Alland Island eye disease and a newly found related disease with X-chromosomal inheritance. Acta Ophthalmol (Copenh) 1991;69:703-10.

26 Forsius $\mathrm{H}$, Eriksson AW. Ein neues Augensyndrom mit Xchromosomaler Transmission. Ein Sippe mit Fundusalbinismus, Fovealhypoplasie, Nystagmus, Myopie, Astigmatismus und Dyschromatopsie. Klin Monatsbl Augenheilkd 1964;144:447-57.

27 Nicholson LVB, Johnson MA, Bushby KMD, et al. Integrated study of 100 patients with Xp21 linked muscular dystrophy using clinical, genetic, immunochemical, and histopathological data. Part 3. Differential diagnosis and prognosis. F Med Genet 1993;30:745-51.
28 Ahn AH, Kunkel LM. The structural and functional diversity of dystrophin. Nature Genet 1993;3:283-91.

29 Schmitz F, Holbach M, Drenckhahn D. Colocalization of retinal dystrophin and actin in postsynaptic dendrites of rod and cone photoreceptor synapses. Histochemistry 1993; 100:473-9.

30 Pillers DM, Bulman DE, Weleber RG, et al. Dystrophin expression in the human retina is required for normal function as defined by electroretinography. Nature Genet 1993;4:82-6.

31 Miyatake $M$, Miike T, Zhao JE, Yoshioka K, Uchino $M$ Usuku G. Dystrophin: localization and presumed function. Muscle Nerve 1991;14:113-19.

32 Fitzgerald KM, Cibis GW, Giambrone SA, Harris DJ. Retinal signal transmission in Duchenne muscular dystrophy: evidence for dysfunction in the photoreceptor/depolarizing bipolar cell pathway. $\mathcal{F}$ Clin Invest 1994;93:2425-30. 